\title{
Functional Electrical Stimulation for Physiotherapy Management of Neurological Conditions: An Evidence Based Study
}

\author{
Dhruva J. Kanojiya ${ }^{1}$, Karishma Jagad ${ }^{2}$ \\ ${ }^{1}$ F. Y M.P.T Student, ${ }^{2}$ Senior Lecturer, \\ Department of Physiotherapy, Government Physiotherapy College, Jamnagar, Gujarat, India
}

Corresponding Author: Dhruva J. Kanojiya

\begin{abstract}
Functional Electrical Stimulation is the electrical stimulation of motor neurons such that muscle groups are stimulated to contract \& create a moment about a joint. In recent years, FES is relatively used as a new therapeutic tool in rehabilitation program of different neurological conditions. Although FES has been used for long time for treating foot drop, there are many studies which support the beneficiary effect to improve upper and lower extremity's function, spasticity, subluxation, respiration, balance, gait training, activities of daily living, quality of life. Multiple databases were searched for relevant articles. The purpose of this study is to evaluate the effectiveness of FES in different neurological condition and to collect the existing literature dealing with FES in a single article to analyze the result $\&$ to finally reach the overall conclusion.
\end{abstract}

Keywords: FES, Stroke, Spinal Cord Injury, Multiple Sclerosis, Parkinsonism.

\section{INTRODUCTION}

Functional Electrical Stimulation is the electrical stimulation of motor neurons such that muscle groups are stimulated to contract and create a moment about a joint. ${ }^{(1)}$ The neurons receive a series of short electrical pulses that are delivered using electrodes. These electrodes can be transcutaneous, percutaneous, epimyseal or cuff. $^{\text {(2) }}$ Application of FES can be independent or dependent. FES independent application is the use of FES for finite time period to minimize impairments and to encourage motor relearning in context of function. FES dependent application is the use of FES that enables the patient to perform functional activities that wouldn't otherwise be possible. Functional Electrical Stimulation was initially referred to as Functional Electrotherapy by Liberson and it was not until 1967 that the term Functional Electrical Stimulation was established by Moe \& Post. The first commercially available FES device treated Foot Drop in hemiplegic patients by stimulating the peroneal nerve during gait. ${ }^{(3)}$

In recent years, FES is relatively used as a new therapeutic tool in rehabilitation program of different neurological conditions like Stroke, Spinal cord injury, Multiple Sclerosis, Parkinson's disease, Cerebral Palsy, Hereditary Spastic Paraparesis, etc. Although FES has been used for long time for treating foot drop, there are many studies which support the beneficiary effect to improve upper and lower extremity's function, spasticity, subluxation, respiration, balance, gait training, activities of daily living, quality of life.

FES application alone or in conjunction with other regular rehabilitation programs for different neurological condition can have a better rehabilitation outcome. The main purpose of this study is to have evidence in order to evaluate the effectiveness of FES in neurorehabilitation. 
Dhruva J. Kanojiya et.al. Functional electrical stimulation for physiotherapy management of neurological conditions: an evidence based study

Another purpose of the present study is to collect the existing literature dealing with Functional Electrical Stimulation in a single article to analyze the results and finally to reach the overall conclusion.

\section{METHODOLOGY}

In order to collect evidences for the effectiveness of FES in different neurological conditions like Stroke, Spinal Cord Injury, Multiple Sclerosis, Parkinsonism, Cerebral Palsy, Hereditary Spastic Paraparesis, Foot Drop, etc. articles were searched and gathered.

The articles were searched in search engines like Google Scholar, PubMed, Cochrane library, Research gate, Elsevier \& Medline. Keywords like FES, Stroke, SCI, Parkinsonism, Cerebral palsy, Paraparesis were used. The reference articles were taken from BioMed Research International, Topic Stroke Rehabilitation, Neurorehabilitation, Physiotherapy Canada, Journal of Physical Therapy, Journal of Spinal Cord Medicine, International Journal of Multiple Sclerosis care, Multiple Sclerosis related Discord, Journal Rehabilitation \& Assistive Technologies Engineering, Developmental Medicine \& Child Neurology, Pediatric Physical Therapy, Journal of Rehabilitation Medicine. These articles were taken with references to explain FES and its effect on different neurological conditions. Guidelines for evidence based clinical practice were adapted from Oxford Centre for Evidence Based Medicine (The Oxford 2011 Level of Evidence).

\section{* Inclusion criteria}

- Articles published from 2010 to 2020.

- Article should be published in English language.

- FES should be used as an intervention either alone or as an adjunct with other physiotherapy rehabilitation.

- Articles finding effect only in neurological conditions.

- Original studies, systematic reviews, randomized controlled trial, quasi experimental studies, interventional studies \& feasibility studies were included.

\section{* Exclusion criteria}

- Language other than English

- Published before year 2010

- Condition other than neurological condition

- Surgical approach used as an intervention

\section{DISCUSSION}

This review summarizes the evidence related to the use of FES in different neurological conditions. Many articles had strong evidence to support the use of FES for upper and lower extremity function, spasticity reduction, gait \& balance improvement and so on.

According to study of Dwen A Howlett et al. ${ }^{(4)}$ FES improves upper and lower limb activity compared with no intervention and training alone. Another study by John Eraifej et al. ${ }^{(\mathbf{1})}$ proves that FES improves motor function and ADL when applied in acute phase (2 months). The reason for not improving in chronic cases might be treatment duration which was short in this study. Another outcome of BBT doesn't found significant improvement might be because of study including BBT as outcome measures was $>1$ year and duration for which it was treated was short. The study done by Amir K Vafadar et al. ${ }^{(5)}$ states that FES doesn't have a significant effect on upper arm motor function early after stroke compared to conventional therapy but can be useful to prevent or treat subluxation. This study used outcome measures which were measuring impairments instead of functional assessment. Outcome measures used for subluxation were X-ray and displacement of head in $\mathrm{cm}$ or $\mathrm{mm}$. FES improved subluxation as it directly stimulates nerve of paralyzed muscle \& produce contraction in those muscles instead of conventional treatment during flaccid phase giving traditional sling and arm supports. 


\section{Table 1: Evidence of FES in STROKE}

\begin{tabular}{|c|c|c|c|c|c|}
\hline Author & $\begin{array}{c}\text { Sample Design/ No of Articles And } \\
\text { Subjects }\end{array}$ & Intervention & Outcome Measures & Result & $\begin{array}{l}\text { Level of } \\
\text { Evidence }\end{array}$ \\
\hline $\begin{array}{l}\text { Owen A. Howlett et al } \\
(2015)^{(4)}\end{array}$ & $\begin{array}{l}\text { A Systematic review with meta- } \\
\text { analysis of FES improving activity after } \\
\text { Stroke } \\
\text { (18 trials }\{8 \mathrm{LL} \& 10 \mathrm{UL}\}-15 \mathrm{RCT} \text {, } \\
\text { 1CCT, } 2 \mathrm{CT} \text { including } 485 \text { patients were } \\
\text { included) }\end{array}$ & $\begin{array}{l}\text { Intervention group received FES (grasping and } \\
\text { releasing activities for UL and gait training } \\
\text { activities for LL) with frequency of ES } 25 \text { to } \\
50 \mathrm{~Hz} \& \text { pulse width } 200-400 \mu \text { s for } 20 \mathrm{mins} \text { to } \\
6 \mathrm{hrs} \text {. FES was applied for } 2 \text { to } 7 \text { sessions per } \\
\text { week for } 2 \text { to } 12 \text { weeks. Control group } \\
\text { received either no intervention or placebo or } \\
\text { same activity training. }\end{array}$ & $\begin{array}{l}\text { For UL: } \\
-\quad \text { Motor Assessment Scale } \\
-\quad \text { Arm Motor Ability Test } \\
-\quad \text { Nine Hole Peg Test } \\
\text { For LL: } \\
-\quad \text { Walking speed }(\mathrm{m} / \mathrm{s})\end{array}$ & $\begin{array}{l}\text { FES has moderate effect on activity (SMD .40; } 95 \% \\
\text { CI) compared with no or placebo intervention. It has } \\
\text { moderate effect on activity (SMD .56; 95\% CI) } \\
\text { compared with training alone. In subgroup analyses, } \\
\text { large effect was found on upper limb activity (SMD } \\
.69 ; 95 \% \mathrm{CI} \& \& \text { small effect on walking speed (mean } \\
\text { diff, .08m/s; } 95 \% \mathrm{CI} \text { ) compared with control group. }\end{array}$ & 1 \\
\hline $\begin{array}{llll}\text { John } & \text { Eraifej } & \text { et } & \text { al. } \\
(2017) & (\mathbf{1})\end{array}$ & $\begin{array}{l}\text { A Systematic review with meta- } \\
\text { analysis in stroke for improvement of } \\
\text { ADL and motor functions in upper } \\
\text { limb. } \\
(20 \text { RCTs of which } 5 \text { studies }=<2 \\
\text { months, 5studies= } 1-3 \text { yrs., 6studies = } \\
>3 \text { yrs })\end{array}$ & $\begin{array}{l}\text { Intervention group received FES with a } \\
\text { frequency of } 20-50 \mathrm{~Hz} \text {, peak current }= \\
\leq 70 \mathrm{~mA} \text { for duration of } 3 \text { to } 10 \mathrm{~s} \text {. Muscle } \\
\text { stimulated were deltoid, triceps, wrist \& finger } \\
\text { flexors/extensors. Control group received } \\
\text { either traditional treatment or sham FES. }\end{array}$ & $\begin{array}{l}\text { Primary: ADL } \\
\text { Secondary: Functional motor } \\
\text { ability } \\
\text { Tertiary: other motor outcomes }\end{array}$ & $\begin{array}{l}3 \text { Studies where FES was initiated on average within } 2 \\
\text { months post stroke showed benefit of FES on ADL } \\
\text { (SMD } 1.24 \mathrm{CI}[0.46,2.03] ; n=32 \text { ). No significant result } \\
\text { was found in other studies where FES was started after } \\
1 \text { year. }\end{array}$ & 1 \\
\hline $\begin{array}{l}\text { Ami K Vafadar et al. } \\
(2015)^{(5)}\end{array}$ & $\begin{array}{l}\text { Systematic review and meta-analysis } \\
\text { improving clinical outcomes in upper } \\
\text { arm. } \\
(9 \text { RCTs and } 1 \text { quasi RCT were } \\
\text { analyzed })\end{array}$ & $\begin{array}{l}\text { Interventional group received FES in addition } \\
\text { to conventional therapy. Supraspinatus and } \\
\text { posterior deltoid were stimulated for } 5 \\
\text { days/week for } 4-8 \text { weeks with a frequency } \\
\text { ranging from } 10 \text { to } 36 \mathrm{~Hz} \text {. Control group } \\
\text { received only conventional treatment. }\end{array}$ & $\begin{array}{l}\text { Shoulder subluxation: } \\
-\quad \text { X ray } \\
-\quad \text { Displacement of head of } \\
\text { humerus in } \mathrm{cm} \text { or } \mathrm{mm} \\
\text { Pain: } \\
-\quad \text { pain during PROM of } \\
\quad \text { lateral rotation } \\
\text { NPRS } \\
\text { Motor Function }\end{array}$ & $\begin{array}{l}\text { Meta analyses showed a significant difference in } \\
\text { shoulder subluxation in experimental groups compared } \\
\text { to control groups, only if FES applied early after } \\
\text { stroke. There is no any significant finding of FES to } \\
\text { improve pain and motor function. }\end{array}$ & 1 \\
\hline $\begin{array}{l}\text { Swati Mehta et al. } \\
\left(2012^{(6)}\right.\end{array}$ & $\begin{array}{l}\text { Systematic review improving gait in } \\
\text { patients with chronic stroke. } \\
\text { ( } 7 \text { RCTs with } 231 \text { patients) }\end{array}$ & $\begin{array}{l}\text { Interventional group received FES via surface } \\
\text { electrodes or implantable electrodes for } \\
\text { walking. The muscle stimulated were gluteal, } \\
\text { hamstrings, quadriceps, dorsiflexors, plantar } \\
\text { flexors and evertors. Some studies used } \\
\text { peroneal nerve stimulation. Frequency varied } \\
\text { between } 4 \text { \& } 20 \mathrm{~mA} \text { and pulse width of } 50 \text { - } \\
450 \mu \mathrm{s} \text {. }\end{array}$ & $\begin{array}{l}\text { 6MWT } \\
\text { 10MWT } \\
\text { FIM }\end{array}$ & $\begin{array}{l}\text { A small but significant treatment effect of FES was } \\
\text { found on } 6 \mathrm{MWT}(0.379 \pm 0.152 ; 95 \% \text { CI, } 0.081- \\
0.677 ; \mathrm{P}=.013)\end{array}$ & 1 \\
\hline $\begin{array}{l}\text { Zhimei Tan et al. } \\
(2014)^{(7)}\end{array}$ & $\begin{array}{l}\text { Randomized controlled trial improving } \\
\text { gait in early stroke } \\
\text { ( } 4 \text { channel FES group } n=16,2 \text { channel } \\
\text { FES group } n=14 \text {, placebo group } n=15 \\
\text { with total of } 45 \text { subjects) }\end{array}$ & $\begin{array}{l}\text { All the subjects were treated in side lying } \\
\text { position with the affected lower extremity } \\
\text { supported by } 2 \text { slings fixed over the knee and } \\
\text { ankle joint. Stimulation was given for } 30 \text { min } \\
\text { per session, } 1 \text { session per day \& } 5 \text { days/week } \\
\text { for } 3 \text { weeks. }\end{array}$ & $\begin{array}{l}\text { Fugl Meyer Assessment, } \\
\text { Postural Assessment Scale for } \\
\text { Stroke patient, Berg Balance } \\
\text { Scale, Functional Ambulation } \\
\text { Category, Modified Barthel } \\
\text { Index }\end{array}$ & $\begin{array}{l}\text { The score of FMA and MBI improved significantly in } \\
\text { four channel group at the end of } 3 \text { weeks training. The } \\
\text { scores of Postural Assessment Scale for Stroke patient, } \\
\text { Functional Ambulation Category, BBS, MBI were } \\
\text { significantly higher than those of placebo group. The } \\
\text { training effects were sustained for at least } 3 \text { months } \\
\text { after treatment. }\end{array}$ & 2 \\
\hline $\begin{array}{l}\text { Ardalan Shariat et al } \\
(2019)^{(8)}\end{array}$ & $\begin{array}{l}\text { A Systematic review with meta- } \\
\text { analysis of cycling with and without } \\
\text { FES on lower limb dysfunction } \\
\text { (14 studies) }\end{array}$ & $\begin{array}{l}\text { Cycling was given as an intervention and } \\
\text { control group was not given any treatment for } \\
\text { the same in few studies. While other included } \\
\text { cycling with FES in one group and only } \\
\text { cycling in comparison group. }\end{array}$ & $\begin{array}{l}\text { Berg balance scale, 6MWT, } \\
\text { 10MWT, and other scales for } \\
\text { measuring mobility and walking } \\
\text { speed }\end{array}$ & $\begin{array}{l}\text { Cycling had a positive effect on 6MWT compared with } \\
\text { no or placebo intervention. Compared with control } \\
\text { cycling had a positive effect on 10MWT, BBS. Cycling } \\
\text { with FES had a positive effect on balance beyond } \\
\text { cycling alone. }\end{array}$ & 1 \\
\hline
\end{tabular}




\begin{tabular}{|c|c|c|c|c|c|}
\hline \multicolumn{6}{|c|}{ Table no 1 continued... } \\
\hline $\begin{array}{l}\text { Jennifer A Robertson } \\
\text { et al. }(2010)^{(\mathbf{9 )}}\end{array}$ & $\begin{array}{l}\text { Pre and post-test interventional study } \\
\text { on balance function and balance } \\
\text { confidence. } \\
\text { (15 subjects with chronic stroke) }\end{array}$ & $\begin{array}{l}\text { Dorsiflexors muscle were stimulated via } \\
\text { peroneal nerve through Velcro cuff which was } \\
\text { attached just below the knee. Change in } \\
\text { pressure triggers the stimulation for balance } \\
\text { and different ambulatory techniques. } \\
\text { Frequency of } 25 \mathrm{~Hz} \text { and } 100 \mathrm{sec} \text { pulse width } \\
\text { was used for } 4 \text { weeks of duration. }\end{array}$ & $\begin{array}{l}\text { Activity Specific Balance } \\
\text { Confidence Scale, Berg Balance } \\
\text { Scale, timed up and go test, gait } \\
\text { speed }\end{array}$ & $\begin{array}{l}\text { Small but statistically improvements in gait (toe } \\
\text { clearance) and balance function can occur during FES } \\
\text { treatment applied to ankle dorsiflexors during swing } \\
\text { phase of gait. Not found significant improvement in } \\
\text { gait speed. }\end{array}$ & 3 \\
\hline $\begin{array}{l}\text { Sang Hyun Moon et al. } \\
(2017)^{(\mathbf{1 0})}\end{array}$ & $\begin{array}{l}\text { Interventional study on effect on } \\
\text { muscle tone \& stiffness of stroke. } \\
\text { (10 subjects) }\end{array}$ & $\begin{array}{l}\text { FES on ankle dorsiflexors (Tibialis anterior) in } \\
\text { sitting position for } 30 \text { minutes for } 5 \text { times a } \\
\text { week for } 6 \text { weeks. Programmed used was } \\
\text { pulse rate of } 35 \mathrm{~Hz} \text {, pulse duration of } 8 \mathrm{sec} \text {, off } \\
\text { pulse duration of } 11 \mathrm{sec} \text {, pulse amplitude of } \\
250 \mu \mathrm{V}\end{array}$ & $\begin{array}{l}\text { Myoton (measured muscle tone } \\
\text { and stiffness of gastrocnemius) }\end{array}$ & $\begin{array}{l}\text { For muscle tone medial and lateral gastrocnemius } \\
\text { muscle showed significant difference of }(\mathrm{p}<0.05) \text {. } \\
\text { Muscle stiffness of medial gastrocnemius }(\mathrm{p}<0.01) \text { and } \\
\text { lateral gastrocnemius }(\mathrm{p}=0.01) \text { were more significant. }\end{array}$ & 3 \\
\hline
\end{tabular}

\begin{tabular}{|c|c|c|c|c|c|}
\hline $\begin{array}{l}\text { EJ McCaughey et al. } \\
(2016)^{(11)}\end{array}$ & $\begin{array}{l}\text { A Systematic review and meta-analysis } \\
\text { of abdominal FES to improve } \\
\text { respiratory functions. } \\
(14 \text { studies, of which } 10 \text { acute and } 4 \\
\text { chronic) }\end{array}$ & $\begin{array}{l}\text { Intervention was stimulation of either or both } \\
\text { rectus abdominis muscle and external oblique } \\
\text { muscle with } 2,4 \text { or } 8 \text { electrodes during } \\
\text { respiration. Mean pulse width was } 259 \mu \mathrm{s} \text {, } \\
\text { frequency of } 50 \mathrm{~Hz} \text {, median maximum } \\
\text { amplitude of } 100 \mathrm{~mA} \text {. Conventional treatment } \\
\text { was strengthening of abdominal muscles. }\end{array}$ & $\begin{array}{l}\text { Cough peak flow, PEF, FEV1, } \\
\text { MEP, FVC, VC }\end{array}$ & $\begin{array}{l}\text { Abdominal FES found a significant acute improvement } \\
\text { in CPF, FEV1. A significant chronic increase in } \\
\text { unassisted VC, FVC, PEF was found. }\end{array}$ & 1 \\
\hline $\begin{array}{l}\text { Anas R. Alashram } \\
\text { et al.(2020) }\end{array}$ & $\begin{array}{l}\text { A Systematic review of spasticity } \\
\text { reduction with FES cycling } \\
\text { (10 studies: } 2 \text { RCT, } 2 \text { cohort, } 6 \text { pilot) }\end{array}$ & $\begin{array}{l}\text { Intervention was FES with cycling and the } \\
\text { placement of electrodes were over quadriceps, } \\
\text { hamstring and gluteal muscle. }\end{array}$ & $\begin{array}{l}\text { Modified Ashworth Scale, } \\
\text { pendulum test, Numerical rating } \\
\text { scale- spasticity, Patient reported } \\
\text { impact of spasticity measure }\end{array}$ & $\begin{array}{l}\text { Significant reduction in MAS and NRS-spasticity } \\
\text { scores }(\mathrm{p}<0.05) \text { after FES cycling post treatment, and } \\
\text { at } 3 \& 6 \text { months. It is considered suitable intervention } \\
\text { for medically stable SCI patients with an indication of } \\
\text { lower extremity movements. }\end{array}$ & 1 \\
\hline 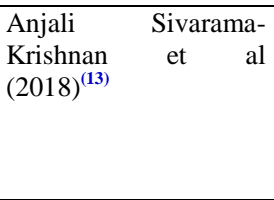 & $\begin{array}{l}\text { A pilot randomized cross over trial of } \\
\text { comparing TENS and FES for } \\
\text { spasticity reduction. } \\
\text { (10 subjects with lower limb spasticity) }\end{array}$ & $\begin{array}{l}\text { One group received FES with pulse rate } 35 \\
\mathrm{~Hz} \text {, pulse width } 300 \mu \mathrm{s}, \text { ramp up }=3 \mathrm{~s} \text {, hold }= \\
5 \mathrm{~s} \text {, ramp down }=2 \mathrm{~s} \text {. another group received } \\
\text { TENS with pulse duration of } 300 \mu \mathrm{s} \text {, frequency } \\
\text { of } 100 \mathrm{~Hz} \text {. Intervention was for } 30 \text { mins and } \\
\text { single session. }\end{array}$ & $\begin{array}{l}\text { Modified Ashworth Scale (hip } \\
\text { adductors, knee extensors, ankle } \\
\text { plantar flexors) } \\
\text { Spinal cord assessment tool for } \\
\text { spastic reflex (SCATS). }\end{array}$ & $\begin{array}{l}\text { Between group analysis did not showed significant } \\
\text { improvement }(\mathrm{p}>0.05) \text {. In within group analyses } \\
\text { spasticity reduction was found upto } 4 \mathrm{hrs} \text { in hip } \\
\text { adductors \& knee extensors }(\mathrm{p}<0.01) \text {. SCATS value } \\
\text { showed significant improvement at } 1 \mathrm{hr} \text { following } \\
\text { TENS and } 4 \text { hrs following FES }(\mathrm{P}=0.01)\end{array}$ & 2 \\
\hline $\begin{array}{l}\text { Naaz Kapadia et al. } \\
(2014)^{(14)}\end{array}$ & $\begin{array}{l}\text { A Randomized trial for walking in } \\
\text { incomplete SCI. }\end{array}$ & $\begin{array}{l}\text { Interventional group received FES stimulation } \\
\text { while ambulating on body weight support } \\
\text { treadmill and harness system. Muscle } \\
\text { stimulated were bilateral quadriceps, } \\
\text { hamstring, dorsiflexors and plantar flexors } \\
\text { with pulse amplitude of } 8-125 \mathrm{~mA} \text {, pulse } \\
\text { width of } 0 \text { - } 300 \mu \text { s and frequency of } 40 \mathrm{~Hz} \text { for } \\
3 \text { days a week for } 16 \text { weeks. }\end{array}$ & $\begin{array}{l}\text { Functional independence } \\
\text { measure, Spinal cord } \\
\text { independence measure (SCIM), } \\
\text { 6MWT, 10 MWT, Modified } \\
\text { ashworth scale, timed up and go } \\
\text { test, Walking mobility score, an } \\
\text { assistive device score. }\end{array}$ & $\begin{array}{l}\text { FES therapy for walking resulted in improved } \\
\text { voluntary therapy walking function, but it was not } \\
\text { superior to an equal dose of aerobic and resistance } \\
\text { training except SCIM sub mobility sub score which } \\
\text { improved in interventional group. }\end{array}$ & 2 \\
\hline $\begin{array}{l}\text { Margot Bergmann et } \\
\text { al.(2019) }\end{array}$ & $\begin{array}{l}\text { A Crossover trial on trunk muscle tone } \\
\text { and dynamic sitting balance in chronic } \\
\text { SCI } \\
\text { (18 subjects) }\end{array}$ & $\begin{array}{l}5 \text { subjects with SCI were alternately allocated } \\
\text { to two study groups; FES +therapeutic } \\
\text { exercise and only therapeutic exercise. } 8 \\
\text { control subjects were taken. FES was applied } \\
\text { to erector spinae and rectus abdominis muscle } \\
\text { for a period of } 30 \text { min for } 6 \text { weeks. }\end{array}$ & $\begin{array}{l}\text { Myotone (muscle oscillation } \\
\text { frequency) Dynamic sitting } \\
\text { balance (limits of stability) }\end{array}$ & $\begin{array}{l}\text { MOF in interventional group increased by } 6 \% \text { for ES } \\
\text { and } 6.1 \% \text { for RA muscle. LOS of flexion increased } \\
30.1 \% \text { in interventional group while increase. After } 7- \\
\text { months break period, a slight decline in trunk muscle } \\
\text { tone and extensive decline in sitting balance value was } \\
\text { noticed. }\end{array}$ & 3 \\
\hline
\end{tabular}




\begin{tabular}{|c|c|c|c|c|c|}
\hline $\begin{array}{l}\text { Miller et al. } \\
(2017)^{(16)}\end{array}$ & $\begin{array}{l}\text { A Systematic review and meta-analysis } \\
\text { for foot drop FES on impact of gait } \\
\text { speed. } \\
\text { (19 studies) }\end{array}$ & $\begin{array}{l}\text { Peroneal nerve stimulation was used for foot } \\
\text { drop. Some articles used surface electrodes } \\
\text { single channel or dual channel, while some } \\
\text { used implanted electrodes. }\end{array}$ & $\begin{array}{l}\text { 10-meter walk test, } 25 \text {-foot walk } \\
\text { test, gait speed over } 6 \mathrm{MWT}\end{array}$ & $\begin{array}{l}\text { Short walk test showed significant initial orthotic effect } \\
(\mathrm{p}=0.016) \text { with mean increase in gait speed of } 0.05 \mathrm{~m} / \mathrm{s} \\
\& \text { ongoing orthotic effect }(\mathrm{p}=0.003) \text { with a mean } \\
\text { increase of } 0.08 \mathrm{~m} / \mathrm{s} \text {. no significant improvement in } \\
\text { long walk test was found. }\end{array}$ & 1 \\
\hline $\begin{array}{l}\text { Linda Miller Renfrew } \\
\text { et al. }(2019)^{(17)}\end{array}$ & $\begin{array}{l}\text { A Systematic review on health-related } \\
\text { quality of life } \\
\text { ( } 8 \text { studies) }\end{array}$ & $\begin{array}{l}\text { Most articles included common peroneal nerve } \\
\text { stimulation for foot drop, while one used } \\
\text { gluteal stimulation in addition. }\end{array}$ & $\begin{array}{l}26-\text { item multiple sclerosis } \\
\text { impact scale, } 36 \text { item short form } \\
\text { health status survey, Canadian } \\
\text { occupational performance } \\
\text { measure, psychological impact } \\
\text { of assistive device scale }\end{array}$ & $\begin{array}{l}\text { FES has significant effect on speed and energy cost of } \\
\text { walking \& HRQOL (such as impact of MS perceived } \\
\text { activities of daily living performance, competence, } \\
\text { self-esteem and confidence in adults with MS) }\end{array}$ & 1 \\
\hline $\begin{array}{l}\text { Shmuel Springer et al. } \\
(2017)^{(\mathbf{1 8})}\end{array}$ & $\begin{array}{l}\text { A Systematic review on gait } \\
\text { (12 studies) }\end{array}$ & $\begin{array}{l}11 \text { out of the } 12 \text { studies used peroneal } \\
\text { stimulation for treatment of foot drop, \& one } \\
\text { study added a } 2^{\text {nd }} \text { channel of stimulation } \\
\text { activating the gluteal muscles to provide hip } \\
\text { extension } \& \text { abduction during stance phase. } \\
\text { Surface electrodes were used in all studies. }\end{array}$ & $\begin{array}{lcr}\text { Walking } & \text { speed, } & \text { walking } \\
\text { endurance, } & \text { Gait } & \text { kinematics, } \\
\text { Falls, Health status } & \end{array}$ & $\begin{array}{l}\text { Most found significant orthotic effect, mainly on } \\
\text { walking speed. Only three studies assessed therapeutic } \\
\text { effect, which was not significant. }\end{array}$ & 1 \\
\hline
\end{tabular}

\begin{tabular}{|c|c|c|c|c|c|}
\hline $\begin{array}{l}\text { Livia Popa 40Hzet al } \\
(2015)^{(19)}\end{array}$ & $\begin{array}{l}\text { A Feasibility study on bradykinesia } \\
\text { (11 subjects) }\end{array}$ & $\begin{array}{l}\text { Group } 1 \text { received stimulation of wrist, finger } \\
\text { and thumb extensors. Group } 2 \text { received } \\
\text { stimulation of intrinsic muscles of hand. } \\
\text { Stimulation parameters used were frequency } \\
40 \mathrm{~Hz} \text {, pulse width } 180 \mu \mathrm{s} \text {, on time } 5 \mathrm{~s} \text {, off time } \\
5 \mathrm{~s} \text {, ramp time } 2 \mathrm{~s} \text {. Both groups received } \\
\text { common peroneal stimulation in swing phase } \\
\text { of gait with pulse width } 180 \mu \mathrm{s} \& \text { frequency } \\
40 \mathrm{~Hz} \text {. Intervention was given for } 2 \text { weeks. }\end{array}$ & $\begin{array}{l}\text { Walking speed, step length, } \\
\text { cadence, Tinetti Balance score, } \\
\text { Box and Block test, Modified } \\
\text { Parkinson's disease quality of } \\
\text { life questionnaire, } \\
\text { SPES/SCOPA scale. }\end{array}$ & $\begin{array}{l}\text { There was significant improvement in } \text { walking } \\
\text { speed(p=0.002), step length }(\mathrm{p}=0.007), \text { cadence } \\
(\mathrm{p}=0.045), \text { Tinetti balance score }(\mathrm{p}=0.006) \text {, BBT } \\
(\mathrm{p}=0.025), \quad \text { PDQL }(0.013), \quad \text { SPES/SCOPA } \\
\text { score }(\mathrm{p}=0.005)\end{array}$ & 4 \\
\hline
\end{tabular}

\begin{tabular}{|c|c|c|c|c|c|}
\hline $\begin{array}{l}\text { Irene Moll et al } \\
(2017)^{(20)}\end{array}$ & $\begin{array}{l}\text { A Systematic review of ankle } \\
\text { dorsiflexors during walking } \\
\text { (14 articles with } 127 \text { patients) }\end{array}$ & $\begin{array}{l}\text { Surface electrodes or percutaneous electrodes } \\
\text { were used to apply peroneal nerve stimulation } \\
\text { with biphasic or monophasic waveform, pulse } \\
\text { width of } 3-350 \mu \text { s with varying pulse } \\
\text { frequency. }\end{array}$ & $\begin{array}{l}\text { Classified based on ICF (activity } \\
\text { and participation level, body } \\
\text { structure and function) }\end{array}$ & $\begin{array}{l}\text { At ICF participation and activity level, there is limited } \\
\text { evidence for a decrease in self-reported frequency of } \\
\text { toe drag and falls. At ICF body structure and function } \\
\text { level, there is clear evidence that FES increased ankle } \\
\text { dorsiflexion angle, strength, motor control, balance and } \\
\text { gait kinematics, but decreased walking speed. }\end{array}$ & 1 \\
\hline $\begin{array}{l}\text { Hsiu Ching Chiu et al. } \\
(2014)^{(\mathbf{2 1})}\end{array}$ & $\begin{array}{l}\text { A Systematic review on activity } \\
(5 \text { RCTs) }\end{array}$ & $\begin{array}{l}\text { Experimental group received FES while } \\
\text { performing an activity such as walking. The } \\
\text { control group had to receive either no } \\
\text { intervention or placebo FES intervention or } \\
\text { activity training that was consistent with the } \\
\text { experimental group. }\end{array}$ & $\begin{array}{l}\text { Walking speed, } \\
\text { Gross motor } \\
\text { measurement }\end{array}$ & $\begin{array}{l}3 \text { trials reported statistically significant between group } \\
\text { difference in favor of FES compared with no FES. } 2 \\
\text { trials reported no statistically significant between group } \\
\text { difference of FES compared with activity training } \\
\text { alone. }\end{array}$ & 1 \\
\hline
\end{tabular}




\begin{tabular}{|c|c|c|c|c|c|}
\hline $\begin{array}{l}\text { Jonathan Marsden et } \\
\text { al.(2012) }\end{array}$ & $\begin{array}{l}\text { Comparative study on walking } \\
\text { (11 subjects with SP and } 11 \text { control) }\end{array}$ & $\begin{array}{l}\text { Peroneal nerve stimulation was given to } \\
\text { interventional group. Control group didn't } \\
\text { receive FES }\end{array}$ & $\begin{array}{l}\text { Muscle torque \& ankle motion, } \\
\text { perceived efficacy, clinical } \\
\text { outcome measures and walking } \\
\text { kinematics }\end{array}$ & $\begin{array}{l}\text { FES increases dorsiflexors torque, improves toe } \\
\text { clearance \& dorsiflexion in swing phase, and } \\
\text { significantly improves walking speed }(\mathrm{p}<0.05)\end{array}$ & 3 \\
\hline $\begin{array}{l}\text { Sarah Prenton et al. } \\
(2016)^{(23)}\end{array}$ & $\begin{array}{l}\text { A Meta-analysis of orthotic effect (FES } \\
\text { vs AFO) } \\
\text { (7 RCTs) }\end{array}$ & $\begin{array}{l}\text { Three trials used customized AFO, one used } \\
\text { off-the shelf AFO, one used combination, one } \\
\text { trial used surface FES, one trial highlighted } \\
\text { clinicians set FES for measurement }\end{array}$ & Based on ICF domains & $\begin{array}{l}\text { FES showed comparable improvements in walking } \\
\text { speed over } 10 \mathrm{~m}(\mathrm{p}=0.04-0.79) \text {, functional exercise } \\
\text { capacity }(\mathrm{p}=0.10-0.31) \text {, timed up and go }(\mathrm{p}=0.821 \text { and } \\
\mathrm{p}=0.539) \& \text { perceived mobility }(\mathrm{p}=0.80) \text { for both } \\
\text { interventions. }\end{array}$ & 1 \\
\hline
\end{tabular}

\section{*Abbreviations}

10MWT - 10 Meter Walk Test

6MWT - 6 Minute Walk Test

ADL - Activities of Daily Living

BBS - Berg Balance Scale

BBT - Box and Block Test

CCT - Controlled Clinical Trial

$\mathrm{CI}$ - Confidence Interval

CT - Controlled Trial

ES - Electrical Stimulation

FEV1 - Forced Expiratory Volume in 1 second

FIM - Functional Independence Measure

FMA - Fugl Meyer Assessment

FVC - Forced Vital Capacity

HRQOL - Health Related Quality of Life

ICF - International Classification of Functioning, Disability and

Health

LOS - Limits of Stability

MBI - Modified Barthel Index
MEP - Maximum Expiratory Pressure

MOF - Muscle Oscillation Frequency

NPRS - Numerical Pain Rating Scale

NRS spasticity - Numerical Rating Scale for Spasticity

PDQL - Parkinson Disease Quality of Life Questionnaire

PEF - Peak Expiratory Flow rate

PROM - Passive Range of Motion

RA - Rectus Abdominis

RCT - Randomized Controlled Trial

SCATS - Spinal cord assessment tool for spastic reflex

SCI - Spinal Cord Independence Measure

SCOPA - Scales for Outcome in Parkinson's Disease

SMD - Standard Mean Difference

SPES/SCOPA - Short Parkinson Evaluation Scale

VC - Vital Capacity 
Thus, FES improves subluxation in patient having stroke of $<6$ months and on follow up after 4 and 12 weeks no improvement was seen. So, FES can be given to improve upper and lower extremity function in acute and chronic stages with higher treatment duration.

Gait abnormality has major affections in stroke patients. Some studies were done in acute \& chronic stages finding significant improvement with FES by peroneal nerve stimulation. Swati Mehta et al. ${ }^{(6)}$ concluded that FES improves gait speed and walking in chronic stroke patients. The study by Zhimei Tan et al. ${ }^{(7)}$ suggest that four channel FES improves motor function, balance, walking ability, \& performance of ADL in subjects with acute stroke. Ardanlan Shariat et $\mathrm{al}^{(\mathbf{8})}$ concluded that FES combined with cycling has significant improvement in balance and gait. A study by Robertson et al ${ }^{(9)}$ concluded that FES to dorsiflexors improves toe clearance, walking, turning, ascending \& descending stairs, ramps, crossing obstacles, walking over different surface. There is evidence which suggest FES improves Spasticity which can be explained by its action on increased Ib fiber activation via mechanism that facilitate the Renshaw cell recurrent inhibition \& on increasing cutaneous sensory stimuli. Sang Hyun Moon et al ${ }^{(\mathbf{1 0})}$ concluded that FES improves calf spasticity.

FES improves respiratory functions, spasticity, gait, independence \& balance in patient with complete or incomplete spinal cord injury in acute and chronic cases. Ej McCaughey et al. ${ }^{(11)}$ conducted a study on abdominal FES, and found significant improvement in acute and chronic effect of respiratory functions. The acute effect of abdominal FES on CPF and FEV1 can be explained by the fact that applied stimulation increases intrathoracic pressure. The improvement in chronic effect on FVC and PEF is suggestive because of increase in abdominal muscle strength. Spasticity reduction is seen following SCI with cycling combined with FES. ${ }^{(12)}$ One study when compared FES with TENS for spasticity reduction found significant improvement in individual group but no significant difference was seen between group, which suggest that TENS or FES can be given alternatively for spasticity reduction in lower limb which works on mechanism of reciprocal inhibition ${ }^{(\mathbf{1 3})}$. A study was done by Naaz Kapadia et al. ${ }^{(14)}$ on walking competency, who found that FES improves walking function in incomplete SCI, but was not superior to an equal dose of aerobic and resistance training. FES assisted walking was found superior with respect to SCIM mobility subscore which was significantly higher. Effect of FES on balance was studied by Margot Bergmann et al. ${ }^{(15)}$ who found the effect on muscle oscillation frequency and limits of stability in terms of muscle tone of trunk muscles and dynamic sitting balance which was statistically significant when FES was given with therapeutic exercise, but when follow up after 7 months break period, a slight decline in trunk muscle tone and extensive reduction in sitting balance values was noticed.

Strong evidence suggests that FES when applied for foot drop in patients with Multiple Sclerosis has initial and ongoing orthotic effect on gait speed in short walking test and also has significant effect on energy cost of walking and HRQOL such as impact of MS perceived activities of daily living performance, competence, selfesteem and confidence in adults with MS. Studies were done in which peroneal nerve stimulation was given for foot drop. ${ }^{(\mathbf{1 6 - 1 8})}$

Liva Popa et al. ${ }^{(\mathbf{1 9})}$ conducted a study finding effect on bradykinesia in Parkinsonian patients. Modest improvement in upper limb function was noted when compared to lower limb. Some participants also noticed increased amount of walking. There is also strong evidence suggesting effect of FES is more effective for improving gait in patients with cerebral palsy than no FES intervention but has similar effect to activity training alone. FES can be used as an alternative to classic orthotic treatment. Rather than being used 
routinely in clinical practice, it might be useful for those children who find exercise program difficult due to their level of disability of poor concentration or cognitive problems. ${ }^{(20)(21)}$

Hereditary spastic paraparesis can lead to multiple impairments such as weakness \& spasticity. Symptoms mainly affect both legs \& result in difficulties with standing, balance and walking. Marsden J Stevenson ${ }^{(22)}$ conducted a study finding effect of FES on dorsiflexors thereby improving walking. FES may aid walking by improving toe clearance and ankle dorsiflexion. A study done by Prenton et $\mathrm{al}^{(\mathbf{2 3})}$ concluded that FES has a significant effect in patients with foot drop in different neurological condition but can be used as an alternative to ankle foot orthosis.

\section{CONCLUSION}

FES has a strong evidence to improve motor functions in upper and lower extremity, gait \& ADL in stroke patients. There is also a strong evidence of additive effect of FES to improve spasticity in lower limb in stroke patients. FES has a strong evidence to improve respiratory function (abdominal FES) and spasticity of lower limb in SCI. FES also improves gait in Multiple sclerosis \& Cerebral Palsy through peroneal nerve stimulation.

\section{Acknowledgement: None}

Conflict of Interest: There was no personal or institutional conflict of interest for the study.

\section{Source of Funding: None}

\section{REFERENCES}

1. Eraifej J, Clark W, France B, Desando S, Moore D. Effectiveness of upper limb functional electrical stimulation after stroke for the improvement of activities of daily living and motor function: a systematic review and meta-analysis. BioMed Central 2017;6(1):40:1-21.

2. Cheryl L. Lynch, Milos R. Popovic. Functional Electrical Stimulation. IEEE
Control System Magazine. 2008;28(2):4050.

3. Aris Papachristos. Functional Electrical Stimulation in Paraplegia. Topics in Paraplegia, Greece: Yannis Dionyssiotis, IntechOpen, 2014. p.109-126.

4. Howlett OA, Lannin NA, Ada L, McKinstry C. Functional electrical stimulation improves activity after stroke: A systematic review with meta-analysis. Arch Phys Med Rehabil. 2015 May;96 (5):934-43.

5. Vafadar AK, Côté JN, Archambault PS. Effectiveness of functional electrical stimulation in improving clinical outcomes in the upper arm following stroke: A systematic review and metaanalysis. BioMed Research International. 2015; 2015:729-768.

6. Pereira S, Mehta S, McIntyre A, et al. Functional Electrical Stimulation for Improving Gait in Persons With Chronic Stroke. Top Stroke Rehabil. 2012 NovDec;19(6):491-8.

7. Zhimei Tan, Huihua Liu, Tiebin Yan, et al. The effectiveness of functional electrical stimulation based on a normal gait pattern on subjects with early stroke: A randomized controlled trial. Biomed Res Int. 2014;2014:545408

8. Shariat A, Najafabadi MG, Ansari NN et al. The effects of cycling with and without functional electrical stimulation on lower limb dysfunction in patients post-stroke: A systematic review with meta-analysis. NeuroRehabilitation. 2019;44(3):389-412.

9. Robertson JA, Eng JJ, Hung C. The Effect of Functional Electrical Stimulation on Balance Function and Balance Confidence in Community-Dwelling Individuals with Stroke. Physiother Can. 2010 Spring;62 (2):114-9.

10. Moon SH, Choi JH, Park SE. The effects of functional electrical stimulation on muscle tone and stiffness of stroke patients. J Phys Ther Sci. 2017 Feb;29 (2)238-41.

11. Mccaughey EJ, Borotkanics RJ, Gollee H, et al. Abdominal functional electrical stimulation to improve respiratory function after spinal cord injury: a 
systematic review and meta-analysis. Spinal Cord. 2016 Sep;54(9):628-39.

12. Alashram AR, Annino G, Mercuri NB. Changes in spasticity following functional electrical stimulation cycling in patients with spinal cord injury: A systematic review. J Spinal Cord Med. 2020 May 14:1-14.

13. Sivaramakrishnan A, Solomon JM, Manikandan N. Comparison of transcutaneous electrical nerve stimulation (TENS) and functional electrical stimulation (FES) for spasticity in spinal cord injury-A pilot randomized cross-over trial. J Spinal Cord Med. 2018 Jul; 41(4):397-406.

14. Kapadia N, Masani K, Catharine Craven $\mathrm{B}$, et al. A randomized trial of functional electrical stimulation for walking in incomplete spinal cord injury: Effects on walking competency. J Spinal Cord Med. 2014 Sep;37(5):511-24.

15. Bergmann M, Zahharova A, Reinvee M, et al. The Effect of Functional Electrical Stimulation and Therapeutic Exercises on Trunk Muscle Tone and Dynamic Sitting Balance in Persons with Chronic Spinal Cord Injury: A Crossover Trial. Medicina (Kaunas). 2019 Sep 21;55(10):619.

16. Miller L, Mcfadyen A, Lord AC, et al. Functional Electrical Stimulation for foot drop in Multiple Sclerosis : A Systematic Review and Meta-Analysis of the impact on gait speed. Arch Phys Med Rehabil. 2017 Jul;98(7)1435-1452.

17. Miller Renfrew L, Lord AC, Warren J, Hunter R. Evaluating the Effect of Functional Electrical Stimulation Used for Foot Drop on Aspects of Health-Related Quality of Life in People with Multiple Sclerosis A Systematic Review. Int J MS Care. 2019 Jul-Aug;21(4)173-82.
18. Springer S, Khamis S. Effects of functional electrical stimulation on gait in people with multiple sclerosis - A systemic review. Mult Scler Relat Disord. 2017 Apr; 13:4-12.

19. Popa L, Taylor P. Functional electrical stimulation may reduce bradykinesia in Parkinson's disease: A feasibility study Functional electrical stimulation may reduce bradykinesia in Parkinson's disease: A feasibility study. J Rehabil Assist Technol Eng. 2015 Oct 26;2: 2055668315607836.

20. Moll I, Vles JSH, Soudant DLHM, et al. Functional electrical stimulation of the ankle dorsiflexors during walking in spastic cerebral palsy: a systematic review. Dev Med Child Neurol. 2017 Dec; 59(12):1230-1236.

21. Chiu HC, Ada L. Effect of Functional Electrical Stimulation on Activity in Children with Cerebral Palsy: A Systematic Review. Pediatr Phys Ther. 2014;26(3):283-8.

22. Marsden J, Stevenson V, Mcfadden C,et al. The Effects of Functional Electrical Stimulation on Walking in Hereditary and Spontaneous Spastic Paraparesis. Neuromodulation. 2013 May-Jun;16 (3): 256-60.

23. Prenton S, Hollands KL, Kenney LP. Functional Electrical Stimulation Versus Ankle Foot Orthoses For Foot-Drop: A Meta-Analysis Of Orthotic Effects. J Rehabil Med. 2016 Oct 5;48(8):646-656.

How to cite this article: Kanojiya DJ, Jagad K. Functional electrical stimulation for physiotherapy management of neurological conditions: an evidence based study. International Journal of Science \& Healthcare Research. 2021; 6(3): 422-430. DOI: https:// doi.org/10.52403/ijshr.20210769 